\title{
Politeness in E-mail of Konferensi Linguistik Universitas Airlangga (KLUA) 2018 Presenters: Cyberpragmatics Review
}

\author{
Ni Wayan Sartini, Universitas Airlangga
}

\begin{abstract}
Nowadays, e-mail is kind of cyber media used widely in various fields including academics. The committees of Konferensi Linguistik Universitas Airlangga (KLUA) 2018 use e-mail for sending and receiving messages from the speakers. This article discusses the politeness strategy in e-mails that speakers sent to the committees. The method of attentive observation and comprehensive reading are applied to identify the politeness strategy in approximately $110 \mathrm{e}-$ mails while data analysis uses the theory and politeness strategy of Brown and Levinson (1987) referring to Mariric's analysis model (2000). The result shows that the speakers use two kinds of politeness strategies: positive and negative. However, in the frequency of use, more speakers tend to use the negative one -indicating formality and deference for the committees. Related to the parameters for weighing politeness, in this term, variable power $(\mathrm{P})$ of the committees influences the selection of politeness strategy used by the presenters of KLUA 2018.
\end{abstract}

Keywords: committee of KLUA; e-mail; politeness strategy; power; speaker

\section{Introduction}

Politeness is an important factor in maintaining a relationship and for harmonization. Yus (2011) identified that "Politeness is a typical human strategy that aims to foster human relations and mitigate the imposition of certain actions on other people." Meanwhile, Escandel Vidal (1996a) defined politeness as "a set of social norms, established by each culture, that regulates adequate behavior of its members, prohibiting some and favoring others," yet she also stressed its importance in the specific context of conversational interaction (Yus, 2011). In addition, Spencer-Oatey (2000) stated that politeness is often interpreted as referring to the use of relatively formal and deferential language such as formal terms.

Various definitions regarding politeness have been explained by the scholars, but in a traditional way, the essence of politeness emphasizes the harmonious aspect of social relations. Therefore, the politeness is not only substantial in face-to-face communication, but also in cyber communication. Even though communication via internet is virtual, ethics should be considered (cyberpragmatics). Politeness is essential in avoiding and minimizing friction between personal interactions (Lakoff,1977) as well as the threat of certain acts (Brown \& Levinson, 1987). On the internet, the expression of politeness is also common and often compulsory, which indicates its importance beyond face-to face interaction (Yus, 2011). In terms of type, politeness in internet is called nettiquette (from the net and etiquette). Others define it as chatiquette-when politeness is used in chat rooms. Cyber media ethic covers communication strategies in internet to produce electronic messages.

Keeping up with time, e-mail now is a widely used cyber media. What is e-mail mainly used for? As one of the fast and priceless social media, e-mail is used for certain purposes, such as for communication between people, the spread of information, and also product promotion. In addition, education sector or academic uses e-mail to send message or information. Furthermore, e-mail is mostly used by conference committees to spread information about local and international upcoming conferences.

The committees of Konferensi Linguistik Universitas Airlangga (KLUA) are also e-mail users for spreading information and receiving messages from the conference participants. Various tribes, religions, races, and nations send messages via e-mail to KLUA's committees. From hundred e-mails sent, there are several forms of message ranging from the long messages to one-sentence messages. Variation in e-mails can be observed from the choice of diction and its grammatical variation. Every e-mail sent to the committees is a discourse containing various 
language aspects-whereas language politeness aspects are interesting to be reviewed. They are within linguistics code like word selection and sentence form (grammar). Kasper (1990) illustrated that the linguistic encoding of politeness strategies is derived from the linguistic system and conventionalized rule of use, such as everyday formula and idioms that tend to be specific to the language.

This article aims to discuss politeness strategy applied by the speakers of KLUA 2018 from e-mails sent to the committees. The participants of KLUA 2018 itself come from various countries, for example: Hongkong, USA, China, Taiwan, Poland, Australia, Africa, Malaysia, Russia, UK, Japan, and Indonesia. With various cultural backgrounds of the participants, politeness model in text applied in e-mails sent to the committees is expected to be revealed.

\section{Literature Review}

A review against how information is produced and interpreted in internet is known as cyber pragmatics. Cyber pragmatics is introduced by Yus (2011) who defined cyber pragmatics as cognitive pragmatics study of Internet-mediated communication along with the development of computer-mediated communication (CMC) theory. As the new emergence of development theory of pragmatics in internet communication area, cyber pragmatics becomes the most suitable theory for analyzing cyber-communication in all cyber-media. Cyber pragmatic was coined in 2001 for a cognitive pragmatics study of internet-mediated communication (Yus, 2011). It is also interested in how users access contextual information in order to fill in the informative gaps between what the users type on the keyboard and what they really intended to communicate.

To analyze the politeness in e-mail of the conference participants, politeness theory of Brown and Levinson (1987) is applied. Brown and Levinson's early work on politeness has had a major impact on the research field (1978/1987). They were the first to propose a systematic model of politeness and while there has been much criticism of their work, many theorists still adhere to a great deal of their terminology and concepts even though some elements of the approach used by Brown and Levinson have since been modified (Mills, 2017). Brown and Levinson characterized politeness as consisting of two elements: negative and positive politeness. Negative politeness largely concerns with not imposing on the other people and indicating deference and respect towards them. In other words, negative politeness is the desire that the speaker's intensions are not prevented by the interlocutors. Meanwhile, positive politeness concerns with stressing the closeness between the speaker and the hearer and indicating that the needs of hearer and the speaker are very similar. Referring to Brown's theory, paying someone a compliment or telling them a joke as a positive politeness, as both of these are seen to be concern with stressing the closeness of the relationship between interactors.

Brown and Levinson (1987) suggested three variables that influence the choice of politeness strategy: relative power $(\mathrm{P})$ of the addressee towards speaker; social distance (D) that includes intimacy and familiarity between the interlocutors; ranking of imposition (R) of an act on the interlocutor's face. The application of Brown and Levinson's strategy model refers to Mariric's study (2000) on the Linguist List. In the Linguist List, some examples of politeness strategy differences referring to theory of Brown and Levinson are explained.

\section{Methodology}

The data was collected from e-mails sent by the participants of KLUA from abstract submission until full paper submission on March-June 2018. The method of attentive observation and comprehensive reading were applied to identify the politeness strategy. Identified politeness aspects were classified to define the politeness type and strategy used by the participants by using Brown and Levinson's theory (1987). The data was then arranged in Mariric's table (2000), presenting politeness type, strategy, linguistics realization, and data examples. 


\section{Result and Discussion}

The discussion of politeness strategy in conference participant e-mails refers to the model that applied by Mariric (2000) Politeness Strategy on The Linguist List (Yus, 2011). This table is slightly modified-bald on record strategy is not included. It only consists of the discussion of positive and negative politeness, linguistics realization, and data examples.

Analysis of the e-mail politeness among KLUA 2018 participants finds two types of politeness strategies: positive and negative politeness. The following table shows the politeness strategy used by the conference participants.

Table 1: Politeness Strategies on E-mail of KLUA2018 Presenter

\begin{tabular}{|c|c|c|}
\hline $\begin{array}{c}\text { On record, } \\
\text { Positive Politeness } \\
\end{array}$ & Linguistics Realization & Example \\
\hline \multicolumn{3}{|l|}{ 1. Claiming common ground } \\
\hline $\begin{array}{ll}\text { - } & \text { Noticing/ attending the } \\
\text { address } \\
\text { - } & \text { In group identity markers } \\
- & \text { Seeking agreement } \\
- & \text { Avoiding disagreement } \\
- & \text { Exaggeration } \\
\end{array}$ & $\begin{array}{ll}\text { - } & \text { informal salutation } \\
\text { - } & \text { informal thanking } \\
- & \text { markers as address form } \\
\text { - } & \text { common opinions, views } \\
\text { - } & \text { hedges } \\
- & \text { overstatement } \\
\end{array}$ & $\begin{array}{ll}\text { - } & \text { Thanks (4) } \\
\text { - } & \text { Dear Colleague } \\
\text { - } & \text { perhaps } \\
\text { - } & \text { I am really excited! } \\
\text { - } & \text { I highly hope that ... }\end{array}$ \\
\hline \multicolumn{3}{|l|}{ 2. Focusing on cooperation } \\
\hline - Assuming cooperation & $\begin{array}{l}\text { use of optimistic } \\
\text { expressions }\end{array}$ & $\begin{array}{l}\text { Thank you very much } \\
\text { for your kind help } \\
\text { - Thank you so much for } \\
\text { your help and kindness }\end{array}$ \\
\hline $\begin{array}{c}\text { On record, } \\
\text { Negative Politeness }\end{array}$ & Linguistics Realization & Example \\
\hline \multicolumn{3}{|c|}{ 1. Giving freedom of action (being generous) } \\
\hline $\begin{array}{l}\text { Not assuming that } \mathrm{H} \text { is } \\
\text { able/willing to help (being } \\
\text { pessimistic) }\end{array}$ & $\begin{array}{l}\text { - } \text { Question, hedges, if clauses } \\
\text { - Tentative modals } \\
\text { could/would }\end{array}$ & $\begin{array}{l}\text { Could you kindly } \\
\text { confirm if it is possible } \\
\text { to pay this on site? } \\
\text { - If there are problems } \\
\text { about this submission, } \\
\text { please let me know } \\
\text { - Could you reserve me a } \\
\text { hotel, please? }\end{array}$ \\
\hline \multicolumn{3}{|l|}{ 2. Minimizing threat } \\
\hline $\begin{array}{l}\text { Showing deference (being } \\
\text { respectful) }\end{array}$ & $\begin{array}{l}\text { - Use of formal politeness } \\
\text { formula and politeness } \\
\text { marker }\end{array}$ & 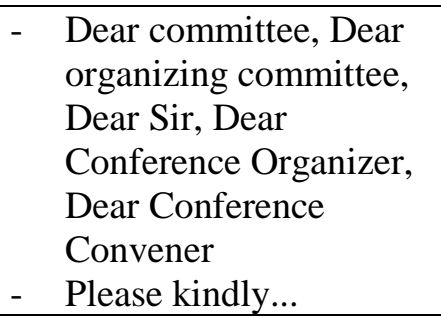 \\
\hline
\end{tabular}


Table 1, cont.

\begin{tabular}{|c|c|c|}
\hline Minimizing imposition & & \\
\hline $\begin{array}{ll}\text { - } & \text { Going on record as } \\
\text { incurring debt } \\
\text { - } & \text { Apologizing } \\
\text { - } & \text { Dissociating the requester } \\
\text { from impingement }\end{array}$ & $\begin{array}{l}\text { - Expression of appreciation } \\
\text { - Use of direct or implied } \\
\text { apologize }\end{array}$ & $\begin{array}{l}\text { I would be very grateful } \\
\text { if the committee can } \\
\text { accept my paper and } \\
\text { give back ... } \\
\text { - } \\
\text { I'm sorry it is a Chinese } \\
\text { version } \\
\text { - ...so sorry we can } \\
\text { present our paper on } \\
\text { first conference day... }\end{array}$ \\
\hline
\end{tabular}

In Table 1, provides information about the KLUA 2018 participants that apply two politeness strategies, namely positive and negative politeness.

\subsection{Positive Politeness Strategy}

Positive politeness strategies applied are claiming common ground with the sub strategies noticing the address, avoiding disagreement, and exaggeration. The linguistic realizations are informal thanking; hedges and overstatement. The use of the word "thanks" is considered as informal thanking, but formal thanking like "thank you" is found more. Avoiding disagreement strategy is in the form of hedges-the use of word "perhaps", which is a language tool that can minimize speech violence impact. According to Fasold (1990), this word is a kind of hesitancy that mitigates speech violence impact. Using that form, the speakers do not impose their desires to the committees. The following strategy is an exaggeration with overstatement as the linguistic realization, for instance, "I am really excited." This speech shows intimacy and closeness between the speakers and the committees. According to Brown and Levinson, the use of positive politeness strategy indicates that there is a close social distance and similarity between others as found in the use of "thanks" or any casual word that reflects intimacy and informality.

Related to parameters for weighing politeness, Brown and Levinson suggested three variables that influence the strategy selection, which are: relative power of the addressee and the speaker $(\mathrm{P})$, social distance that includes intimacy and familiarity between the interlocutors (D) and ranking of imposition on the interlocutor's face (R). The use of positive politeness strategy of the speakers to the committees is affected by social distance (D) between KLUA committees and related participants.

\subsection{Negative Politeness Strategy}

The negative politeness strategies in the e-mails sent to KLUA committees are giving freedom of action (being generous), minimizing threat, and minimizing imposition. Each strategy has a sub strategy. From the table, it is clear that the application of negative politeness strategies can be seen in question, hedges, if clauses, and the use of tentative modals, such as "could/would" and all of these are politeness markers and formal politeness formula. Talking about formal politeness formula, it is found in some form variations, such as: Dear Committee, Dear Organizing Committee, Dear Sir, Dear Conference Convener, etc, and all followed by politeness markers, like please kindly..., please find, please check, I would like... In pragmatics, this included in sub strategy showing deference (being respectful)-a strategy that gives deference to the committees. As Brown and Levinson uttered, the use of negative politeness strategy shows the formality among participants. It is also largely concerned with not imposing on the other person and indicating deference and respect toward them. Hence, apologizing can be categorized as negative politeness strategy application, for example: sorry it is a Chinese version, and...so sorry we can present our paper on first conference day...In line with parameters for weighing politeness, the variation of application between negative politeness strategy and its sub strategy in the form of politeness formula present relation of power $(\mathrm{P})$ in both the speakers and the committees. 


\section{Conclusion}

From the data analysis above, the speakers use two politeness strategies: positive and negative politeness. However, the speakers tend to use the negative politeness strategy where it is a formal politeness strategy that indicates deference towards the committees. In line with parameters for weighing politeness, it shows a vertical relationship reflecting the power relationship $(\mathrm{P})$ where the committees considered more powerful than participants. In this review, it is concluded that the difference of politeness strategy with its various markers, either formal or informal, expression is a source to understand how the speakers position themselves to maintain relationship and social harmony between the speakers and the committees.

\section{References}

Brown, P., \& Levinson, S. C. 1987. Politeness: Some Universal in Language Use. Cambridge: Cambridge University Press.

Vidal, V. E. 1996a. Introduction a la Pragmatica. Barcelona: Ariel.

Fasold, R. 1990. The Sociolinguistics of Language. Oxford: Basil Blackwell.

Lakoff, R. 1977. What you can do with words: politeness, pragmatics, and performatives. Texas Conference on Performatives, apresuppositions and Implicatures, Andy Roger, Bob Wall and John P Murphy (eds), 79-106. Arington (USA): Center for Applied Linguistics.

Mariric, I. 2000. Cyberpoliteness: Requesting strategies on the Linguist List. Seventh Conference of International Pragmatics Assotiation, Budapest (Hungary), July.

Mills, Sara. 2017. Language, Culture, and Politeness. In Sharifian, F (ed.). The Routledge Handbook of Language and Culture. London and New York: Routledge.

Spencer-Oatey, H. 2000. Culturally Speaking. Managing Rapport through Talk across Cultures. London: Continuum.

Yus, F. 2011. Cyberpragmatics. Internet-Mediated Communication in Context. Amsterdam: John Benjamin Publishing Company. 